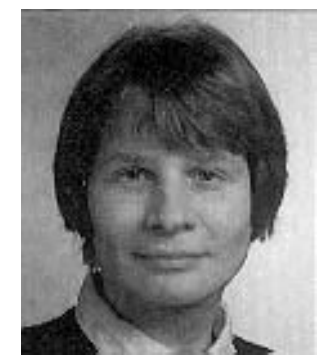

Mirjami Korhonen

\title{
Opiskelijan perhe - kivireki vai energian antaja?
}

\section{Onko perhe opiskelevalle aikuiselle tuki vai taakka? Perhe ottaa ja antaa. Perheen merkitys henkisenä ja taloudellisena voimana on osoittautunut kuitenkin sen aiheuttamaa taakkaa suuremmaksi. Keskeisen tärkeää on jäsenyys perheryhmässä.}

Tässä artikkelissa selostetaan osa ammattikorkeakoulujen opiskelija-aineiston tutkimustuloksista, jotka on koottu perheen ja opiskelun yhteensovittamisen selvittämiseksi. Perheellisyyden kriteerinä oli se, että opiskelijalla on vähintään yksi lapsi ja oletuksena se, että perheellisillä on jonkinasteisia ongelmia perhevelvoitteiden ja koulunkäynnin yhteensovittamisessa. Tavoitteena oli selvittää, miten perheen olemassaolo vaikuttaa opiskelijan arkeen. Aineisto kerättiin yhden ammattikorkeakoulun sosiaali- ja terveysalan perheellisiltä opiskelijoilta $(n=22)$, jotka ovat osallistuneet kokonaistutkimuksen aiempiin vaiheisiin ja opiskelivat viimeistä lukuvuotta tietojenkeruun aikana marraskuussa 1996. Tietojenkeruumenetelmänä käytettiin keskustelujen lisäksi avoimia kysymyksiä sisältänyttä kyselylomaketta. Vastaukset saatiin 20 opiskelevalta vanhemmalta, joiden joukossa on sekä miehiä että naisia.

Tarkastelun kohteena ovat lähinnä opiskelijoiden vastaukset perheen merkityksestä ja opiskelijan orientaatioista. Perhe tuo opiskeluaikaiseen elämään rasitteita, joita ovat ennen kaikkea työn määrä ja ajan käytön rajoitteet. Niistä huolimatta perhe on useimmille tuki, jota ilman ei olisi tullut opiskeltua laisinkaan. Ominaista perheellisille opiskelijoille oli myös pyrkimys hakeutua yhteistyöhön toisten perheellisten kanssa. Aluksi esitellään opiskelijoiden myönteisiä ja kielteisiä kuvauksia perheen merkityksestä. Toiseksi kuvataan perheellisten opiskelijoiden orientaatioita, jotka ilmentävät ulkoisia opiskeluolosuhteita ja kuvaavat opiskelijan asennoitumista opintoihin ja elämään. Lopuksi pohditaan aikuisen opiskelijan elämänpiiriä ja keinoja, jotka helpottaisivat opiskelun ja perheen yhteensovittamista.

\section{Perhe rasitteena ja tukena}

Syyllisyys ja väsymys -sanat kuvasivat opiskelijoiden haitallisia tuntemuksia. Perhettä pidettiin monella tavalla takkana. Huonoa omatuntoa aiheutui siitä, että lasten kanssa olemiseen ei ollut aikaa niin paljon kuin olisi haluttu. Perheellisiä opiskelijoita kadutti useasti jälkeenpäin se, etteivät he ehtineet huoltaa kaik- 


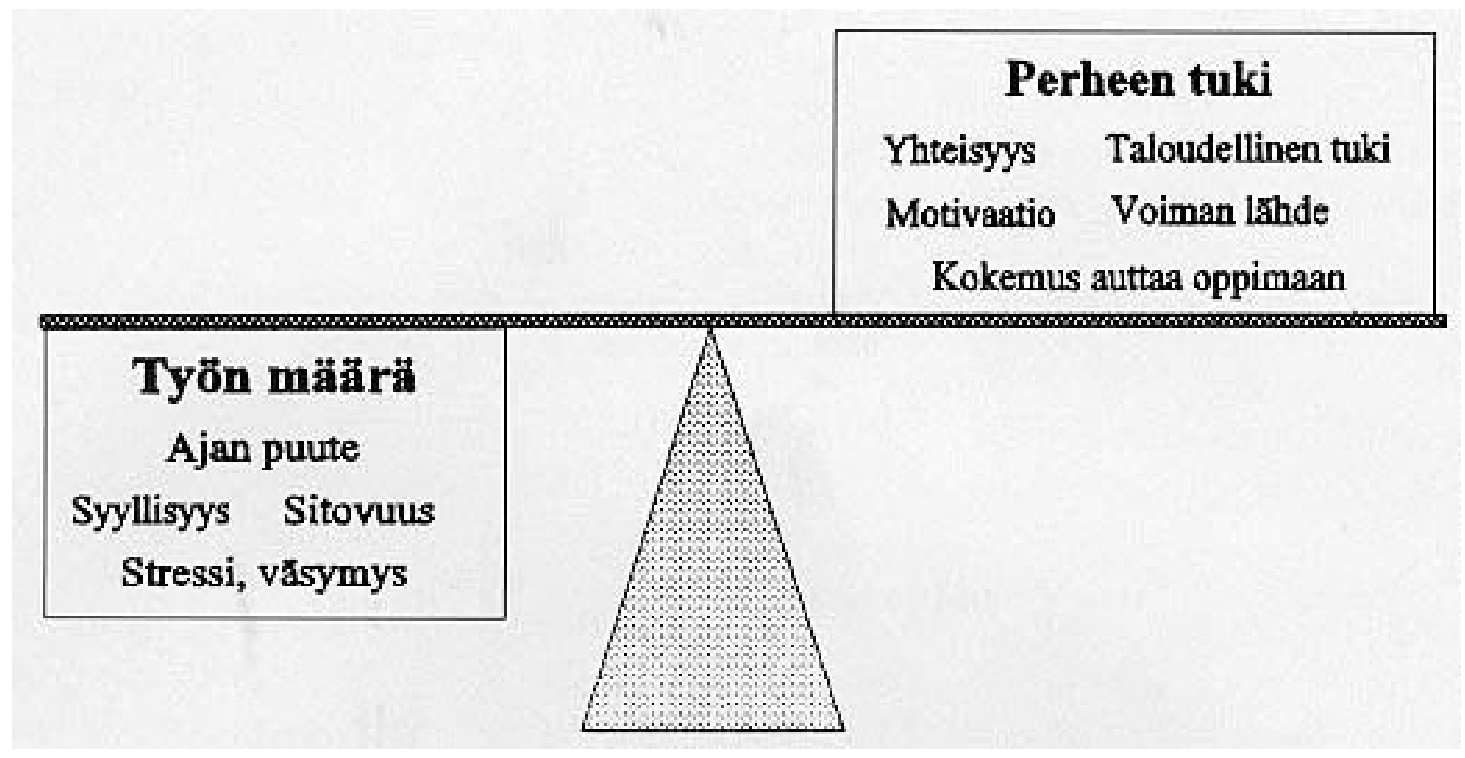

Kuvio 1.Myönteisiä ja kielteisiä kokemuksia perheestä opiskelun aikana

kea sitä, mitä ennen opiskelun aloittamista olivat tottuneet tekemään. Tekemättömät kouluja kotityöt aiheuttivat stressaantumista ja väsyttivät. Myös yöunet jäivät usein lyhyiksi. Työmäärä kasvoi perheenjäsenten lukumäärän mukaan etenkin silloin, kun lapset olivat pieniä, eniten hoivaa ja huoltamista tarvitsevia. Lapset kuluttivat rahaa ja perheen menot oli otettava jatkuvasti huomioon niin rahan kuin ajankin käytön suunnittelussa.

Ä̈riesimerkkinä voisi kuvata Sarin, joka kabden pienen lapsen vanhempana oli rybtynyt opiskelemaan. Lasten pieni ikäero heijasti vanhemman väsymystä, koska synnytysten jälkeinen palautumisvaibe oli jäänyt lybyeksi ja pienet lapset vaativat runsaasti huolenpitoa. Ansiotyönsä vuoksi puoliso joutui olemaan poissa kotoa ja sukulaisia ei ollut paikkakunnalla. Lapsista toisella oli lähes jatkuva korvatulehdus ja toisella synnynnäinen sydänvika. Perbe asui vuokraasunnossa, jonka lämmitysjärjestelmä oikutteli kovilla pakkasilla. Myös anopilta lainaksi saatu kulkuneuvo ilmaisi toiveita rahanpuntteen vuoksi lykätystä auton huollosta juuri silloin, kun sitä kipeimmin olisi tarvittu.
Tällaisessa ympäristössä koulunkäynti luonnollisesti kärsii ja ainakin koulumenestyksen ennuste on heikko. Tavoitteen asettaminen epäonnistuu kerta toisensa jälkeen ja poissaoloja koulusta tulee väistämättömästi. Tehtävät jäävät rästiin eikä muiden opiskeluvauhdissa mukana pysyminen onnistu. Toisen perheellisen opiskelijan osa on erilainen.

Merjan opiskelun aloittaminen on buolellisesti suunniteltu, ja se on ajoitettu mabdollisimman stabiiliin elämänvaiheeseen, jossa muita muntoksia on odotettavissa vähän. Lapsi on aloittanut koulunkäyntinsä, oppinut käymään itsenäisesti iltapäiväkerhossa ja tulemaan ajoissa kavereiden luota kotiin. Puoliso buolebtii tai avustaa kotitöissä ja kauppa-asioiden hoitamisessa. Isovanhemmat tulevat tarvittaessa lapsen seuraksi tai kuljettavat bäntä harrastuksiin. Koti on omistusasunto, jossa on riittävästi tilaa myös lapsen kavereille. Opiskelevalle vanhemmalle löytyy rauballista työskentelytilaa, ja käytössä oleva tietotekniikka tarjoaa välineet tebtävien tekemiseen.

Useimmat perheelliset opiskelijat sijoittuvat näiden ääriesimerkkien välille ja heidän opiskelutilanteessaan on piirteitä molemmista 
tapauksista. Olosuhteet perheissä vaihtelevat myös paljon. Sairaus paranee, autolle tehdään remontti, velkoja lyhennetään ja kodinkoneita uusitaan. Tutkimusaineistossa oli myönteisten ilmaisujen määrä paljon suurempi kuin kielteisten ilmaisujen määrä. Siitä voidaan päätellä, että perheen tuki opiskelijalle on hyvin tärkeä.

Opiskelijoiden myönteiset ilmaisut on ryhmitelty neljään eri alueeseen:

\section{1) Perhe tukee ja antaa voimaa.}

Perheen taloudellinen merkitys on suuri. Puolison tulot, pysyvä koti ja olemassa oleva varallisuus luovat sen pohjan, jolle tilapäinen opiskelu voidaan rakentaa. Puoliso auttaa ja tukee, on kiinnostunut opinnoista, henkinen tuki ja opiskelun hyväksyminen ovat merkittäviä.

\section{2) Perhe kompensoi epäonnen.}

Perhe toimii siten, että opiskelija voi purkaa kotona huolensa, murheensa ja epäonnistumiset koulussa. Perheenjäsenet kuuntelevat vuodatukset ja sekin helpottaa. Perhe opettaa suhteuttamaan esille tulevat asiat oikeisiin mittoihin ja sen mukana suhtautumaan opiskeluun

\section{3) Perhe motivoi suorituksiin.}

Perhe antaa uskoa ja motivoi selviytymään opinnoista. Suhtautuminen opiskeluun on tehokkaampaa ja vakavampaa perheen ansiosta.

\section{4) Perhe antaa etäisyyttä opintoihin.}

Perheen ilot ja surut auttavat irrottautumaan kouluasioista. Jo kotimatkalla alkaa virittyä päälle uusi henkinen ohjelmakanava.

\section{Perheellisen opiskelijan orientaatiot}

Orientaatioita kartoitettiin kysymällä, millainen on ollut perheellisen opiskelijan "opiskelijaelämä“. Perheelliset opiskelijat ymmärtävät opiskelijaelämällä useimmiten iltamenoja ravintoloissa, olutiltoja, tapaamisia, järjestötoimintaa ja liikkumista kaduilla suurissa opiskelijajoukoissa. He kuvaavat tätä opiskelijaelämän sosiaalista aluetta sanalla "rilluttelu“, jonka he katsovat kuuluvan kaukaisena asiana ainoastaan muille opiskelijoille ja johon perheelliset eivät ehdi osallistua.

Oman opiskelijaelämänsä kuvaamisessa perheelliset opiskelijat ryhmittyivät neljään ryhmään.

\section{1) Sopeutujat}

ovat niitä, joiden avio- tai avopuoliso osallistuu kotitöihin, suhtautuu myönteisesti opintoihin ja tukee niissä selviytymistä. Opiskeluaika on lähentänyt perhettä ja lisännyt sen yhteenkuuluvuutta. Asioista on sovittu yhdessä ja tasapainoilua opiskelun ja perheen välissä on toteutettu.

\section{2) Nautiskelijat}

pitävät opiskelua asiana, joka antaa mahdollisuuden omien rajojen löytämiseen ja kykyjen testaamiseen. Kouluruokailu on heille kuin juhla-ateria, jonka aikana ei tarvitse syöttää ketään. Nautiskelijat palkitsevat itsensä silloin tällöin herkkuhetkillä ja he viihtyvät myös hiljaisuudessa. He käyttävät usein kirjastoa lukupaikkanaan ja tekevät tehtäviä kodin ulkopuolella yhdessä toisten opiskelijoiden kanssa.

\section{3) Syylliset}

potevat huonoa omaatuntoa ajan puutteen vuoksi. He kantavat huolta lapsistaan silloinkin, kun nämä ovat päivähoidossa tai koulussa. Tekemättömät työt haittaavat keskittymistä, koulutehtävistä nähdään painajaisia ja seuraavan päivän tehtävät pyörivät ajatuksissa. Huolta aiheuttavat myös ne taloudelliset menetykset ja uhraukset, joita opiskelu on vaatinut. Syylliset selviytyvät lohduttamalla itseään sillä, että menossa on vain tilapäinen elämänvaihe.

\section{4) Kiireiset}

kiiruhtavat kodin, lapsen päivähoitopaikan, koulun ja kaupan välillä. Aamulla noustaan nopeasti nukkumasta, keitetään aamupuuro, herätetään lapset, joudutaan ajoissa kouluun ja koulupäivän päätyttyä tehdään samat asiat päinvastaisessa järjestyksessä. "Kun perheetön miettii, menisikö illalla La Grangeen vai Bistroon (paikallisia ravintoloita), perheellinen 
pohtii ruokaostosten tekoa Prismasta vai lähikaupasta“.

Vastauksista poimittuja ilmauksia voidaan tarkastella myös tavoitteen, toiminnan tai sitoutumisen kannalta. Tavoitteet ilmenevät siten, että opiskelija on tehnyt omavalintaisen päätöksen opiskelun aloittamisesta elämäntilanteensa huomioiden. Aloittamispäätöksen taustalla on voinut olla ajatus hyvinvointiyhteiskunnan oravanpyörän jättämisestä ja sen sijaan sapatin viettämisestä. Opiskelulle on asetettu tavoitteita toisaalta henkilökohtaisten ominaisuuksien kehittymisen suhteen ja toisaalta ammattitaidon kehittämiseksi. Motivoitunut toiminta lisää elämänhallinnan tunnetta.

Vaikka varsinaista aikuisopiskelijatyyppiä ei ole olemassa, on mahdollista havaita erottavia piirteitä varsinkin perheellisten aikuisopiskelijoiden ja nuorempien opiskelijoiden välillä. Tällaisia ovat esimerkiksi rikkaammat ja monipuolisemmat elämänkokemukset ja työhistoriat, erilaiset oppimistyylit ja opiskeluun liittyvät tavoitteen asettelut (Vaherva \& Ekola 1986, 20; Korhonen 1995, 99-100). Näiden seikkojen merkitystä jatkuvan koulutuksen ja henkilökohtaisen elämänpolitiikan näkökulmasta on syytä tarkastella hieman laajemmin. Tämän artikkelin tutkimusaineistoa on tarkasteltu Martonin (1993, 284-285; Uljens 1989, 23) fenomenografiaan perustuvan mikä- ja miten -näkökulman mukaan. Mikä-näkökulman avulla on selvitetty perheellisen opiskelijan olosuhteita ja elämänkonteksteja, joissa hän elää, asuu ja opiskelee. Opiskelijan hyvinvoinnin, opinnoissa menestymisen ja perhe-elämän onnistumisen kannalta näyttää olevan tärkeätä, että kaikilla hyvinvoinnin osa-alueilla asiat ovat jokseenkin kohdallaan.

Having-alueella tarvitaan taloudellisesti turvattuja oloja opiskeluaikana perheen laskevan tulotason vuoksi. Lapsista aiheutuvat menot ovat tutkimusajankohtana lisääntyneet ja opiskelukustannuksetkin voivat tuntua uhrauksilta. Niistä huolimatta perusasiat, kuten asuminen, terveys ja puolison työ antavat turvallisen tunteen. Loving-alueella perheelliset verkostoituvat seu- rustelemalla keskenään ja työskentelemällä yhdessä. Isovanhemmat ja ystävät ovat tärkeimmät avustajat erityisesti tilapäisessä lastenhoidossa. Being-alueella tingitään opintojen takia eniten. Se ilmenee harrastusten, lomailun ja matkailun siirtämisenä myöhempään ajankohtaan. Kuitenkin itsearvostus yleensä kohoaa opiskellessa ja tutkinnon suorittamisen yhteydessä.

Miten-näkökulmaa on sovellettu tarkasteltaessa perheellisten opiskelijoiden arkielämää: kuinka perheelliset pystyvät sovittamaan yhteen koulunkäyntiin liittyviä vaatimuksia ja perheenjäsenten odotuksia, miten he asennoituvat opiskeluaikaansa, miten he ovat tehneet päätöksen opiskelun aloittamisesta, miten he asettavat tavoitteensa, kuinka he sitoutuvat opintoihin ja millainen on aikuinen oppijana.

\section{Opiskelusta elämäntapa}

Opiskelun aloittamispäätös kypsyy usein vähitellen. Joidenkin päätösten taustalla ovat työelämän kiristyneet vaatimukset, tulevaisuuden epävarmuus, motivaation väheneminen entiseen tilanteeseen, vaihtelun halu tai kykenemättömyys toimia työelämässä aikaisemmalla pätevyydellä. Opintojen käynnistymisen syinä Järvinen on maininnut $(1996,31)$ halun kehittyä, ainutkertaisen opiskelutilaisuuden tarjoutumisen, lisäpätevyyden hankkimisen tai opiskelun vain omaksi iloksi. Jotkut ilmoittivat opiskelevansa harrastuksenomaisesti niin, että se on jatkuvaa tai siitä on tullut jopa elämäntapa. Todettakoon, että Järvisen aineisto koostui aikuisopiskelijoista yleensä. He opiskelivat pääsääntöisesti työn ohessa ja saivat opiskeluajalta palkkaa tai olivat työn keskeytyksen aikana opintovapaalla ja säilyttivät työsuhteensa. Useimmilla heistä ei ollut perhettä eikä ainakaan pieniä lapsia. Perheellisistä ammattikorkeakouluopiskelijoista kootun oman tutkimusaineistoni vastauksista ilmeni, että perheelliset kokevat opintonsa tilapäisenä mutta tavoitteellisena toimintana ammatinhankkimisen kannalta.

Opiskelijat pyrkivät huomioimaan opiskelun 
ajoittamisen elämäntilanteeseensa siten, että tilapäinen katkos palkkatuloissa on mahdollinen (Griego 1995; Korhonen 1996; Purhonen 1995). Osa tulojen puutteesta kompensoitui entistä pienemmillä kuluilla ja osa opintotuella. Perheellisen opiskelua verrattiin monessa suhteessa tavanomaiseen työssäkäyntiin. Väliaikaisratkaisut auttoivat siirtämään kodin hankintoja ja muita menoja suunnitelmallisesti tulevaisuuteen. Opiskelun uskottiin tuovan lisäarvoa opiskelevalle vanhemmalle henkilökohtaisesti ja olevan yhteiseksi hyödyksi koko perheelle siinä määrin, että perheenjäsenet olivat valmiit opiskelusta aiheutuviin velvoitteisiin.

Uhrausten motiivina on tiedostettu tavoite. Perhe sitoutuu keinoihin, joilla tavoitteeseen halutaan päästä. Perheelliset opiskelijat näyttävät toteuttavan tavoitteensa asettelussa Rauste-von Wrightin ja von Wrightin $(1995,47)$ selostamaa aktiivista transferia. Se perustuu oppijan pyrkimyksiin toisaalta luoda edellytyksiä transferille jo oppimisvaiheessa, toisaalta käyttää hyväkseen aiemmin opittua uusissa tilanteissa, esimerkiksi yrittämällä löytää tietorakenteiden välisiä yhteyksiä, etsimällä selityksiä ja perusteluja. Tällöin aktiivinen transfer nivoutuu saumattomasti opiskelijan ajatteluprosesseihin ja pohdinnoissa hyödyttyvät oppijan elämän- ja työkokemukset. Perheen merkitys korostuu erityisesti naisvaltaisten alojen koulutuksessa kuten sosiaali- ja terveysalalla sekä kotitalousalan tehtäviin kouluttautumisessa.

\section{Elämänkokemus auttaa oppimaan}

Tavoitteen asettamisen lisäksi opiskelijan asennoitumista opintoihin voidaan käsitellä oppimaan oppimisen näkökulmasta. Monet aikuisopiskelijat ovat aikaisempien koulutustensa jälkeen olleet useita vuosia käytännön työssä tai perhetilanteen vuoksi kotona. Heille on voinut muodostua esteitä kirjallisen ilmaisun harjoittamattomuuden vuoksi. Monilla aikuisopiskelijoilla saattaa koulunkäynnistä olla myös kielteisiä kokemuksia ja muistoja, jotka aktivoituessaan aiheuttavat pelkoja opiskelemaan ryhtymisessä. Pelkoja esiintyy erityisesti iäkkäämmillä opiskelijoilla. Kieli- ja tietotekniikkaopintojen vaatimukset voivat aiheuttaa jopa ahdistusta.

Itsearvostuksella näyttääkin olevan merkittävä osuus oppimisvalmiuksien ylläpitäjänä. Se säätelee ratkaisevasti sitä, missä määrin yksilö on valmis kokeilemaan uusia toimintamalleja ja strategioita ja yleisemminkin toimimaan omaa elämäänsä ohjaavana subjektina. Itsearvostuksen puute aiheuttaa ristiriidan, joka luonnollisesti vaikuttaa oppimiseen. Kysymys "Onko minusta mihinkään?" sitoo vahvasti rajoittuneen tiedon kapasiteetin (Rauste-von Wright \& von Wright 1995, 101). Hyvä koulumenestys on omiaan toimimaan itsearvostuksen lisääjänä.

Tarkasteltaessa perheen osuutta opiskelijan elämässä voidaan todeta, että perhe voi olla monella tavalla myös rasite. Kotitöiden tekeminen ja lapsista huolehtiminen vievät tietysti aikaa, joka on poissa opinnoista ja opiskelijan lepoajasta. Verrattaessa tämän tutkimuksen tuloksia Jokisen (1996) aineistoon yhtäläisyyttä löytyy väsymistä ilmaisevien sanontojen osalta. Erityisesti opiskelevat äidit käyttivät sanaa " väsymys", joka yhdistyi liian lyhyisiin yöuniin. Väsymys ei tosin korostunut siinä määrin kuin Jokisen tutkimuksessa, mutta hän lähtikin väitöskirjatyössään tietoisesti etsimään väsymistä kuvaavia ilmaisuja.

Perheen merkitys henkisenä ja taloudellisena voimana osoittautui rasittavuutta suuremmaksi. Attraktio perheeseen viittaa yhteenkuuluvuuteen, joka kuvaa todellista jäsenryhmää yksilölle. Ilmaukset siitä, miten kotiin tultua unohdetaan isotkin koulumurheet, lataudutaan uusiin suorituksiin ja tunnetaan itsensä tärkeäksi, osoittavat perheryhmän jäsenyyden merkityksen. Kun opiskelijoilla sen lisäksi on opiskeluryhmä, jota Järvisen $(1996,38)$ haastattelemista opiskelijoista kaksi kolmasosaa piti merkityksellisimpänä tekijänä koulutuksen aikana, voidaan ymmärtää, että kiinnittyminen sosiaalisiin verkostoihin on voimakasta. Opiskelijat ovat selvästi aktiivisemmassa asemassa verrattuna työttömien tai kotiäitien tilanteisiin, joilta puut- 
tuu kodin ulkopuolella oleva viiteryhmä ja jotka joutuvat viettämään osan ajasta täysin vailla aikuiskontakteja (Elliot 1991, 126; Korhonen 1994, 66).

\section{Sosiaaliset verkostot opiskelijan tukena}

Alhainen koulutustaso yhdistyy usein hyvinvoinnin puutteeseen myös muilla osa-alueilla. Koulutuksen ulkopuolelle jäämisen syitä ovat pitkät etäisyydet, muuttoliike ja etenkin naisilla perhesyyt. Opintojen esteet ovat usein henkilökohtaisia tunnekysymyksiä muutoksen kokemisesta. Pelko uudesta tilanteesta rajoittaa osallistumista ja estää koulutuksen aloittamisen. Tämä merkitsee sitä, että osa perheellisistä jää koulutuksen ulkopuolelle ja uhka hyvinvoinnin puutteesta lisääntyy. Perheet ovat erilaisia ja tarpeiden huomioiminen koulutusjärjestelyissä vaatii monenlaisia ratkaisuja.

Mitä jatkuvan koulutuksen toteuttamiseksi voidaan tehdä niin, että perheelliset voisivat nykyistä paremmin siihen osallistua? Työssä käyvät, aikaisemmin koulutuksen hankkineet henkilöt voivat saada opiskeluansa varten opintovapaita ja työlomia. Lapsiperheitä koskevat yleiset sosiaalietuudet ovat voimassa opiskelunkin aikana, vaikka niitä on viime vuosina pienennetty ja niiden ehtoja on kiristetty.

Koulutusohjelmien ja opetussuunnitelmien tulisi olla selkeitä, jotta opiskelija pystyisi omaksumaan ne helposti. Vaatimusten pitäisi olla ainakin puitteiltaan sen verran pysyviä, että toisen vuosikurssin opiskelijan neuvot olisivat valideja uusille opiskelijoille. Joustavia ne voisivat olla lähinnä tenttiaikojen ja suoritusjärjestyksen suhteen. Lisäksi oppilaitokset voisivat kehittää kirjastojaan ja järjestää lukutiloja, myös atk-laitteiden käyttömahdollisuus helpottaisi opiskelua. Opiskelutilat voisivat olla avoimena siten, että niissä olisi mahdollista työskennellä vielä oppituntien päätyttyä ja iltaisin. Oppilaitoksessa voisi olla myös erillinen tila, jossa opiskelijoiden lapset voisivat harjoittaa omia opintojaan lukien, kirjoitellen, piirrellen tai tietokonepelejä pelaten.
Opiskelijakaupungeissa voisi toimia opiskelijoiden käyttöön tarkoitettuja toimintakeskuksia. $\mathrm{Ne}$ voisivat perustua nykyisten perhekahviloiden toimintaperiaatteille, jolloin kustannukset olisivat minimaaliset, lapsilla olisi kavereita, ohjattua toimintaa ja ohjelmaa. Vanhemmat voisivat tehdä yhdessä koulutehtäviä, ryhmätöitä, yksilötehtäviä tai lueskella. Toimintakeskuksissa voisi olla tarjolla esimerkiksi teetä ja kahvia, edullista välipalaa ja päivän lehdet. Ehkäpä samassa yhteydessä voisi toimia lastenvaatteiden vaihtotori ja rikkinäisten tavaroiden korjauspalvelu.

Tällaisen toiminnan ylläpitäjiksi sopisivat järjestöt ja muut yhteisöt. Oppilaitosten oppilaskunnat voisivat organisoida vapaaehtoistyöntekijöitä ja mahdollisesti työllistääkin muita henkilöitä. Kannettavien tietokoneiden vuokraustoiminta olisi hyvää palvelua. Mannerheimin Lastensuojeluliitolla voisi olla perhekahvilatoimintaa myös opiskelijoille. Perustietoa on saatavilla hongkongilaisen järjestön yksinhuoltajaperheille toteuttamasta voimavarakeskuksesta, jossa vanhemmat tapaavat toisiaan, lukevat lehtiä ja joissa lapsille on oma leikkinurkkaus (Mulvey 1996, 341-351).

Tällaisesta toiminnasta hyötyisi koko yhteiskunta. Lasten hyvinvoinnin parantaminen silloin, kun vanhemmat ovat kiireisiä, lieventää vastaisia ongelmia. Myös vanhempien syrjäytymisen ehkäiseminen vähentää yhteiskunnan tulevia kustannuksia. Koulutettu työvoima on elinkeinoelämälle ja työmarkkinoille kehittymisen edellytys. Nykyisen kaltaisessa työelämän murrosvaiheessa koulutukseen osallistuminen on ainoa keino pitää työntekijöiden oppimisvalmiudet hyvinä. Opittuja asioita voidaan soveltaa käytännön harjoittelujaksojen lisäksi lyhytkestoisten työsuhteiden aikana. Kaikkia uusia työtehtäviä ei voida riittävästi opetella koulussa, mutta valmius uuden omaksumiseen voidaan luoda.

Opiskelijan kannalta merkittävää on varmuus siitä, että koulutuksella on käyttöä opintojen päättymisen jälkeen. Epätietoisuus tulevaisuudesta yhdessä ammatillisen murroksen kanssa 
ei voi olla aiheuttamatta identiteettikriisiä. Riski on sitä suurempi, mitä turhemmaksi opiskelija on kokenut itsensä entisessä ammatissaan, ja mitä epävarmempaa työn saanti nykyisen koulutuksen jälkeen on. Toiveikkuus lisää itsearvostusta ja helpottaa identiteetin muotoutumista.

\section{Iötes}

ELLIOT, F. R. (1991) The family: Change or continuity? London: Macmillan.

GRIEGO, M. (1995) The pressures and low-income families: The implications for 'social'transport policy in Europe. Community Development Journal. An International Forum. Oxford University Press 30 (4), 347-363.

JOKINEN, E. (1996) Väsynyt äiti. Äitiyden omaelämäkerrallisia esityksiä. Tampere: Gaudeamus.

JÄRVINEN, A. (1996) Aikuisopiskelijan orientaatiot työn ja koulutuksen maastoissa. Tampereen yliopisto. Kasvatustieteiden laitos. Julkaisusarja A. N:o 56.

KORHONEN, M. (1994) Kotiäidin byvinvointi, tyytyväisyys ja tulevaisuuden suunnitelmat. Kajaanin ammattikorkeakoulun julkaisusarja. Julkaisuja 2.

KORHONEN, M. (1995) Perbeellinen opiskelija ammattikorkeakoulussa. Teoksessa K. Korhonen \& R. Mäkinen (toim.) Ammattikorkeakoulut uudistuvina oppimisympäristöinä. Jyväskylän yliopisto. Kasvatustieteiden tutkimuslaitoksen julkaisusarja B. Teoriaa ja käytäntöä 91, 92-103.

KORHONEN, M. (1996) Opiskelun ja perbe-elämän ybteensovittamisen ongelmia ja ratkaisuja. Kasvatus 27 (3), 261-272.

MARTON, F. \& DALL'ALBA, G. \& BEATY, E. (1993) Conceptions of learning. International Journal of Educational Research 19, 277-300.

MULVEY, T. (1996) Single parent families in Hong Kong - a special group with needs unmet. 27 th ICSW Internatiol Gonference. July 29 - August 3, 1996. Conference Proceedings Volume 2b, 341-351.

PURHONEN, A. (1995) ..."ei tässä uskalla ottaa opintolainaa, kireetä on jo muutenkin". Opiskelijoiden tulonläbteet, taloudellinen selviytyminen ja opintolainan käyttö osana toimeentuloa. Helsinki: Stakes. Aiheita 7.

RAUSTE-von WRIGHT, M-L. \& von WRIGHT, J.
(1995) Oppiminen ja koulutus. Porvoo: WSOY. ULJENS, M. (1989) Fenomenografi - forskning om uppfattningar. Lund: Studentlitteratur.

VAHERVA, T. \& EKOLA, J. (1986) Aikuisten opettamisen taito. Radion aikuiskasvatussarjan kolmannen osan oppikirja. Yleisradio/Opetusohjelmat.

Artikkeli saapui toimitukseen 27.2.1997 ja uudelleen kirjoitettu artikkeli maaliskuussa.Toimituskunta teki julkaisupäätöksen 3.4.1997. 